NASSER, MD; MARIANO-NASSER, FAC; BORGES, CV; KOVALSKI, TR; FURLANETO, KA; VIEITES, RL. 2018. The use of active modified atmosphere for the conservation of minimally processed eggplant. Horticultura Brasileira 36: 439-445. DOI - http://dx.doi.org/10.1590/S0102-053620180403

\title{
The use of active modified atmosphere for the conservation of minimally processed eggplant
}

\author{
Mauricio D Nasser ${ }^{1}$; Flávia Aparecida C Mariano-Nasser ${ }^{1}$; Cristine V Borges ${ }^{1}$; Tania Regina Kovalski $^{1}$; \\ Karina Aparecida Furlaneto후 Rogério L Vieites ${ }^{1}$
}

${ }^{1}$ Universidade Estadual Paulista Júlio de Mesquita Filho (UNESP), Botucatu-SP, Brasil; mdnasser@bol.com.br; flaviamariano1@ hotmail.com; cristine.vanzb@gmail.com; tania_kovalski@yahoo.com.br; karina_furlaneto@globo.com; vieites@fca.unesp.br

\begin{abstract}
The aim of this work was to evaluate effects of different gas concentrations $\left(\mathrm{O}_{2}\right.$ and $\left.\mathrm{CO}_{2}\right)$ on conservation of minimally processed eggplants. The eggplants were sanitized, processed and packed in nylon + transparent polyethylene. The vegetables were submitted to modified atmospheres $(\mathrm{T} 1=$ atmospheric air; $\mathrm{T} 2=$ vacuum; $\mathrm{T} 3=4 \%$ $\mathrm{O}_{2}$ and $5 \% \mathrm{CO}_{2} ; \mathrm{T} 4=4 \% \mathrm{O}_{2}$ and $6 \% \mathrm{CO}_{2} ; \mathrm{T} 5=4 \% \mathrm{O}_{2}$ and $7 \% \mathrm{CO}_{2}$; $\mathrm{T} 6=4 \% \mathrm{O}_{2}$ and $8 \% \mathrm{CO}_{2}$ ). The minimally processed eggplants were kept at $5 \pm 1^{\circ} \mathrm{C}$ and $90 \pm 1 \% \mathrm{RH}$, for 10 days. After $0,2,4,6,8$ and 10 days of storage, fresh weight loss, respiratory rate, color, soluble solids (SS), titratable acidity (TA), $\mathrm{pH}, \mathrm{SS} / \mathrm{TA}$ ratio, visual analysis and purchase intent were determined. We used completely randomized experimental design, in a factorial scheme $6 \times 6$ (atmosphere $\mathrm{x}$ days of conservation). The atmosphere with higher $\mathrm{CO}_{2}$ concentration $(8 \%)$ reduced the respiratory rate more intensely. The minimally processed eggplant maintained at $4 \% \mathrm{O}_{2}+6 \% \mathrm{CO}_{2}$ obtained better grades on the visual analysis and purchase intention, with 10-day storage period. The vacuum was not recommended to keep minimally processed eggplant refrigerated under the studied conditions.
\end{abstract}

Keywords: Solanum melongena, quality, storage.

\section{RESUMO}

Atmosfera modificada ativa na conservação de berinjela minimamente processada

Objetivou-se estudar o efeito de diferentes concentrações de gases $\left(\mathrm{O}_{2}\right.$ e $\left.\mathrm{CO}_{2}\right)$ na conservação de berinjela minimamente processada. As berinjelas foram higienizadas, processadas e embaladas em nylon + polietileno transparente. Foram submetidas a atmosfera modificada ( $\mathrm{T} 1=$ ar atmosférico; $\mathrm{T} 2=$ vácuo; $\mathrm{T} 3=4 \% \mathrm{O}_{2}$ e $5 \%$ de $\mathrm{CO}_{2} ; \mathrm{T} 4=4 \%$ $\mathrm{O}_{2}$ e $6 \%$ de $\mathrm{CO}_{2}$; $\mathrm{T} 5=4 \% \mathrm{O}_{2}$ e $7 \%$ de $\mathrm{CO}_{2}$; $\mathrm{T} 6=4 \% \mathrm{O}_{2}$ e $8 \%$ de $\mathrm{CO}_{2}$ ). As berinjelas minimamente processadas foram mantidas a $5 \pm 1{ }^{\circ} \mathrm{C} \mathrm{e}$ $90 \pm 1 \%$ de UR, por 10 dias. Aos 0, 2, 4, 6, 8 e 10 dias de conservação foram determinadas perda de massa fresca, taxa respiratória, coloração, sólidos solúveis (SS), acidez titulável (AT), pH, relação SS/AT, análise visual e intenção de compra. O delineamento experimental utilizado foi inteiramente casualizado, em esquema fatorial $6 \times 6$ (atmosfera $\mathrm{x}$ dias de conservação). A atmosfera com maior concentração de $\mathrm{CO}_{2}(8 \%)$ reduziu mais intensamente a taxa respiratória. A berinjela minimamente processada mantida a $4 \% \mathrm{O}_{2}+6 \% \mathrm{CO}_{2}$ obteve melhores notas na análise visual e intenção de compra no período de 10 dias. $\mathrm{O}$ vácuo não foi recomendado para manter refrigerada berinjela minimamente processada nas condições estudadas.

Palavras-chave: Solanum melongena, qualidade, conservação.

Received on October 13, 2017; accepted on June 29, 2018

E ggplant (Solanum melongena) is an important non-climacteric vegetable largely consumed fresh and wholesome. About 30 millions of tons are produced worldwide (Li et al., 2014). It is considered a low-calorie and low-fat vegetable, a good source of minerals, vitamin B-complex, and phenolic compounds, being also consumed due to its medicinal properties (Shukla \& Naik, 1993). As most fresh products, a growing interest in this vegetable, minimally processed, has been noticed, due to practicality and convenience in meal preparation, product uniformity and reduced post-harvest losses (Russo et al., 2012).
Minimally processed vegetables of fresh fruits, ready to be cooked, show to be convenient and do not have their nutritional and functional properties changed, when compared to fresh product. Despite the advantages in terms of convenience and freshness, cutting and slicing vegetables may lead to quality losses, resulting in water loss, softening, microbiological contamination, changes in chemical composition and production of secondary metabolites. Moreover, increasing respiration and enzymatic activity can be verified, reducing the product shelf life. The main limiting factor which reduces eggplant life is the oxidation of phenolic compounds by polyphenol oxidases (PPOs), which causes browning and, consequently, the depreciation of the final product quality (Ghidelli et al., 2014).

The fast discoloration immediately after cutting is an impediment in its minimal processing. One of the main methods in order to delay these physiological, biochemical and microbiological reduction processes on the crop is the use of modified atmosphere (Fonseca et al., 2002; Li et al., 2014; Steffens et al., 2009; Vieites et al., 2014).

Active modified atmosphere aims to decrease the metabolism of the product, consequently its senescence, through 
partial oxygen reduction and an increase in carbon dioxide concentration; allied with refrigerated storage, this technique is considered a less costly alternative, resulting in an extended shelf life (Steffens et al., 2009; Vieites et al., 2014). It also seems to be a convenient alternative to delay physiological, biochemical and microbiological reduction processes (Arruda et al., 2011). The effect of low $\mathrm{O}_{2}$ concentration and high $\mathrm{CO}_{2}$ concentration to control enzymatic browning and make shelf life longer has been positively reported for several minimally processed fruits and vegetables (Rojas-Grau et al., 2009), including eggplants (Moretti \& Pineli, $2005)$. According to the reports, $2 \%$ of $\mathrm{O}_{2}$ is the critical concentration to possibly cause anaerobic respiration, considering that this limit depends on the product used. However, for fresh eggplants, Catalano et al. (2007) reported that, although the modified atmosphere improves quality preservation during conservation at $4^{\circ} \mathrm{C}$, an increase in $\mathrm{CO}_{2}$ and a decrease in $\mathrm{O}_{2}$ inside the packaging can stimulate PPO activity of the product. Responses for different atmospheres depend mainly on the product used, temperature and storage time. For eggplants, the results found in literature are still scarce. Thus, the aim of this study was to evaluate the effect of different $\mathrm{O}_{2}$ and $\mathrm{CO}_{2}$ concentrations in minimally processed eggplant.

\section{MATERIAL AND METHODS}

Eggplant cv. Ciça was grown on a property in Campinas, São Paulo State, taken to the laboratory of Faculdade de Ciências Agronômicas, UNESP, and selected. The authors eliminated samples showing physical and biological damages aiming to obtain a uniform lot.

After washed in running water in order to take off dirt from harvest and transport, the samples were immersed into sodium hypochlorite solution (200 $\mathrm{mg} \mathrm{L}^{-1}$ ) for 20 minutes. Then, the eggplants were sliced in $1.5-\mathrm{cm}$ thick pieces, eliminating inedible parts. After cutting, the samples were placed in a solution containing $50 \mathrm{mg} \mathrm{L}^{-1}$ of sodium hypochlorite for 20 minutes; afterwards, they were drained, rinsed under running water and immersed into citric acid solution $(2 \%)$ for 10 minutes, in order to prevent browning.

Slices were drained using a colander for 3 minutes and placed in a centrifuge (Consul), for 40 seconds at $2800 \mathrm{rpm}$. Right after, portions of 150 grams were packed in plastic containers (vacuum) of nylon + transparent polyethylene of high oxygen barrier $\left(10 \mathrm{~cm}^{3}\right.$ day $\left.^{-1}\right)$ and water vapor $\left(5 \mathrm{~m}^{2} \mathrm{day}^{-1}\right)$, afterwards submitted to modified atmosphere, with application of gases provided by White Martins Gases. Each cylinder was purchased with the appropriate gas mixture for each treatment: $\mathrm{T} 1=$ atmospheric air, T2= vaccum, T3=4\% $\mathrm{O}_{2}+5 \% \mathrm{CO}_{2}, \mathrm{~T} 4=4 \% \mathrm{O}_{2}+6 \% \mathrm{O}_{2}, \mathrm{~T} 5=$ $4 \% \mathrm{O}_{2}+7 \% \mathrm{CO}_{2}$ and $\mathrm{T} 6=4 \% \mathrm{O}_{2}+8 \%$ $\mathrm{CO}_{2}$. The process consisted of formation of vacuum followed by gas injection and sealing using a vacuum packaging machine (Tec Maq). Control treatment was sealed with ambient air, and then the packages were stored in a cold chamber at $5 \pm 1{ }^{\circ} \mathrm{C}$ temperature and $90 \pm 1 \%$ relative humidity, for 10 days. At 0,2 , 4, 6, 8 and 10 days, three replicates were taken from each treatment and analysed: fresh weight loss, respiratory rate, color, soluble solids (SS), titratable acidity (TA), $\mathrm{pH}, \mathrm{SS} / \mathrm{TA}$ ratio, visual analysis and purchase intent.

Fresh weight loss was calculated using the mass differences of experimental units, being the initial weight of packaging of the minimally processed eggplants used as reference, with the aid of an analytical scale, with 5 replicates and the results expressed in percentage $(\%)$.

Respiratory curve was obtained by titration. Respiratory rate was determined indirectly in a respirometer, measuring $\mathrm{CO}_{2}$ released, following the methodology adapted by Bleinroth et al. (1976). Respiratory rate was calculated using the equation:

$$
\mathrm{TCO}_{2}=\frac{2,2 x(A-B) x V 1}{P x T x V 2}(\text { Equation } 1)
$$

where $\mathrm{TCO}_{2}=$ respiratory rate in $\mathrm{mL}$ of $\mathrm{CO}_{2} \mathrm{~kg}$ of fruit ${ }^{-1}$ hour $^{-1} ; \mathrm{A}=$ the amount of volume of standardized $\mathrm{HCl}$ used as a tritant of standard potassium hydroxide, before $\mathrm{CO}_{2}$ absorption (white); $\mathrm{B}=$ the amount of volume of standardized $\mathrm{HCl}$ used as a tritant of potassium hydroxide after respiration $\mathrm{CO}_{2}$ absorption; $\mathrm{V} 1=$ the amount of volume of potassium hydroxide used in $\mathrm{CO}_{2}$ absorption $(\mathrm{mL}) ; \mathrm{P}=$ mass of minimally processed eggplants $(\mathrm{kg})$; $\mathrm{T}=$ metabolic reaction time (hour); $\mathrm{V} 2=$ the amount of volume of potassium hydroxide used as tritant $(\mathrm{mL}) ; 2.2=$ related to the equivalent to $\mathrm{CO}_{2}(44 / 2)$, multiplied by the concentration of 0.1 $\mathrm{N}$ hydrochloric acid.

Soluble solids were determined by direct reading using a table refractometer, type Palette $\mathrm{PR}-32$, with temperature correction to $20^{\circ} \mathrm{C}$, and results expressed in \%. Titratable acidity was determined in eggplant pulp through titration with $0.01 \mathrm{~N}$ $\mathrm{NaOH}$ solution and phenolphthalein indicator and results expressed in $\mathrm{g}$ citric acid $100 \mathrm{~g}^{-1}$ pulp according to the recommendation of Instituto Adolfo Lutz (Brasil, 2008). The hydrogenion potential $(\mathrm{pH})$ was obtained using the digital potentiometer model DMPH-2 Digimed.

Color was determined at two points, peel and pulp, using Konica Minolta colorimeter model CR400, to determine values (L*, Croma and Hue) (Minolta, 1998).

Visual analysis of minimally processed eggplant was done by 32 nonselected and untrained panelists, using subjective scoring scale taking into consideration the product appearance, where $1=$ very bad, showing fungi (rot); $2=$ bad, dark and fungus-free; $3=$ regular, opaque color and fungus-free (suitable for market); 4=- good, dull and fungus-free; 5= excellent, firm and normal color, being 3 the market acceptance limit. In order to evaluate purchase intent, the authors used 5-point scale according to Meilgaard et al. (1999), where 5= definitely would buy; $4=$ may buy; $3=$ maybe would buy/maybe wouldn't buy; $2=$ probably wouldn't buy and 1= definitely would not buy.

The experiment was carried out in a completely randomized design, in a factorial scheme 6x6 (atmosphere $\mathrm{x}$ days of storage). Percentage values for fresh mass loss were transformed to arcsin square root values (x/100); in order to make the table, original values 
were presented, though. The data were submitted to analysis of variance and means compared using Tukey test, at $5 \%$ probability. Regression analysis was done for storage time.

\section{RESULTS AND DISCUSSION}

Respiratory rate at 6 -day postharvest storage for eggplants stored in air was higher than in other atmospheric conditions, reaching $288.5 \mathrm{~mL} \mathrm{CO}$ $\mathrm{kg}^{-1} \mathrm{~h}^{-1}$ (Figure 1). On day 10 , the authors verified low respiratory rate for all treatments. Decreasing in respiratory activity after climacteric peak is a result of reaction inactivation of enzymes present in the cells on the cut surface with respiratory substrates (Kluge et al., 2014), or due to the change in glycolysis route, synthesis, degradation, inactivation or inhibition of certain enzymes which take part in this metabolic route (Araújo et al., 2005). Similar behavior was reported by Kluge

Table 1. Means of mass loss (\%) and $\mathrm{pH}$ values among treatments of minimally processed eggplants packed under active modified atmosphere during a 10-day storage. Botucatu, UNESP, 2015.

\begin{tabular}{|c|c|c|c|c|c|c|c|}
\hline \multirow{3}{*}{ Treatments } & \multicolumn{7}{|c|}{ Mass loss (\%) } \\
\hline & \multicolumn{7}{|c|}{ Days of storage } \\
\hline & $\mathbf{0}$ & 2 & 4 & 6 & 8 & 10 & Mean \\
\hline Control & 0 & 0.05 & 0.05 & 0.09 & 0.11 & 0.07 & $0.06 \mathrm{ab}$ \\
\hline Vacuum & 0 & 0.00 & 0.00 & 0.01 & 0.05 & 0.09 & $0.02 \mathrm{~b}$ \\
\hline $4 \% \mathrm{O}_{2}+5 \% \mathrm{CO}_{2}$ & 0 & 0.03 & 0.02 & 0.06 & 0.12 & 0.16 & $0.06 \mathrm{ab}$ \\
\hline $4 \% \mathrm{O}_{2}+6 \% \mathrm{CO}_{2}$ & 0 & 0.07 & 0.06 & 0.10 & 0.16 & 0.22 & $0.10 \mathrm{a}$ \\
\hline $4 \% \mathrm{O}_{2}+7 \% \mathrm{CO}_{2}$ & 0 & 0.04 & 0.27 & 0.12 & 0.12 & 0.17 & $0.12 \mathrm{a}$ \\
\hline $4 \% \mathrm{O}_{2}+8 \% \mathrm{CO}_{2}$ & 0 & 0.02 & 0.00 & 0.01 & 0.06 & 0.10 & $0.03 \mathrm{~b}$ \\
\hline CV (\%) & - & - & - & - & - & - & 67.0 \\
\hline \multirow{3}{*}{ Treatments } & \multicolumn{7}{|c|}{ pH } \\
\hline & \multicolumn{7}{|c|}{ Days of storage } \\
\hline & $\mathbf{0}$ & 2 & 4 & 6 & 8 & 10 & Mean \\
\hline Control & 4.38 & 4.88 & 5.02 & 5.25 & 5.18 & 5.12 & $4.97 \mathrm{a}$ \\
\hline Vacuum & 4.38 & 4.56 & 4.71 & 4.77 & 4.57 & 4.57 & $4.59 \mathrm{bc}$ \\
\hline $4 \% \mathrm{O}_{2}+5 \% \mathrm{CO}_{2}$ & 4.38 & 4.44 & 4.54 & 4.88 & 4.60 & 4.89 & $4.62 \mathrm{bc}$ \\
\hline $4 \% \mathrm{O}_{2}+6 \% \mathrm{CO}_{2}$ & 4.38 & 4.59 & 4.70 & 4.96 & 4.85 & 4.78 & $4.71 \mathrm{~b}$ \\
\hline $4 \% \mathrm{O}_{2}+7 \% \mathrm{CO}_{2}$ & 4.38 & 4.63 & 4.62 & 4.72 & 5.02 & 4.70 & $4.68 \mathrm{bc}$ \\
\hline $4 \% \mathrm{O}_{2}+8 \% \mathrm{CO}_{2}$ & 4.38 & 4.53 & 4.57 & 4.60 & 4.48 & 4.58 & $4.52 \mathrm{c}$ \\
\hline CV (\%) & - & - & - & - & - & - & 3.6 \\
\hline
\end{tabular}

*Means followed by same lowercase letter in column do not differ significantly by Tukey test $(\mathrm{p}<0.05)$. et al. (2014) for minimally processed yellow bell pepper. Vacuum and higher oxygen atmospheric $(8 \%)$ treatments showed the lowest respiratory rate, with maximum values close to $107.8 \mathrm{~mL}$ $\mathrm{CO}_{2} \mathrm{~kg}^{-1} \mathrm{~h}^{-1}$. In overall means for mass loss, the values were significantly lower than in 6 and $7 \% \mathrm{CO}_{2}$ treatments (Table $1)$, which anticipated the climacteric peak in relation to the control (at 2-day storage). Theoretically, the use of higher $\mathrm{CO}_{2}$ concentrations decreases respiratory rate, controls physiological changes and, concomitantly, reduces weight loss of the product (Toivonen \& Dedell, 2002), which corroborates the results found in this study.

Regardless of the atmosphere used in this study, mass loss of minimally processed eggplant was only influenced in storage. A linear increasing was verified (Figure 1), possibly in response to the stress caused by the cut during processing, resulting in an increase in respiratory activity (carbohydrate consumption via glycolysis). This increasing mass loss in minimally processed vegetables was also verified for other crops, such as pumpkin (Russo et al., 2012) and beet (Kluge et al., 2006) stored under active modified atmosphere.

A decrease in soluble solids (SS) was verified, overall mean of $4.37 \%$. This reduction may be related to resource consumption for metabolic reactions as well as respiration of minimally processed eggplant. In relation to titratable acidity, a decrease in all treatments was observed (30 to $43 \%$ ) (Table 2). The authors observed $\mathrm{pH}$ changes along the days (Figure 2 ). However, a small increase was observed at the end of storage period, mainly for the control which showed, in overall mean, significantly higher value comparing to the other treatments (under active modified atmosphere) (Table 1). The $\mathrm{pH}$ values are used as an indicator of the microbiota in food for preserving. Thus, $\mathrm{pH}$ values lower or equal to 4.5 do not favor the presence of Clostridium botulinum and other pathogenic bacteria (Hoffmann, 2001). Rinaldi et al. (2009) and Kluge et al. (2014) cited that some studies report that $\mathrm{pH}$ value can increase in response to an increase in microbiota during storage. This phenomenon is characteristic in vegetables deteriorated by Gram-negative bacteria, since protein breakdown results in a release of basic compounds (Jacxsens et al., 2013). Maturation index, obtained by SS/ AT ratio, is a variable which indicates maturation and quality of the material to be analyzed during post-harvest (Chitarra \& Chitarra, 2005). Using the results of regression in table 2 , the authors noticed that on day 6 of storage the values reached higher level and then this level tends to fall. Nevertheless, control treatment showed higher values of maturation index since day 4 of storage. In the same conditions, opposite behavior was reported by Russo et al. (2012), who verified a decrease in SS/AT ratio in all treatments throughout storage, working with minimally processed pumpkin during 12-day storage.

For peel luminosity (Table 3), significant regression was noticed only for the vacuum treatment, considering 


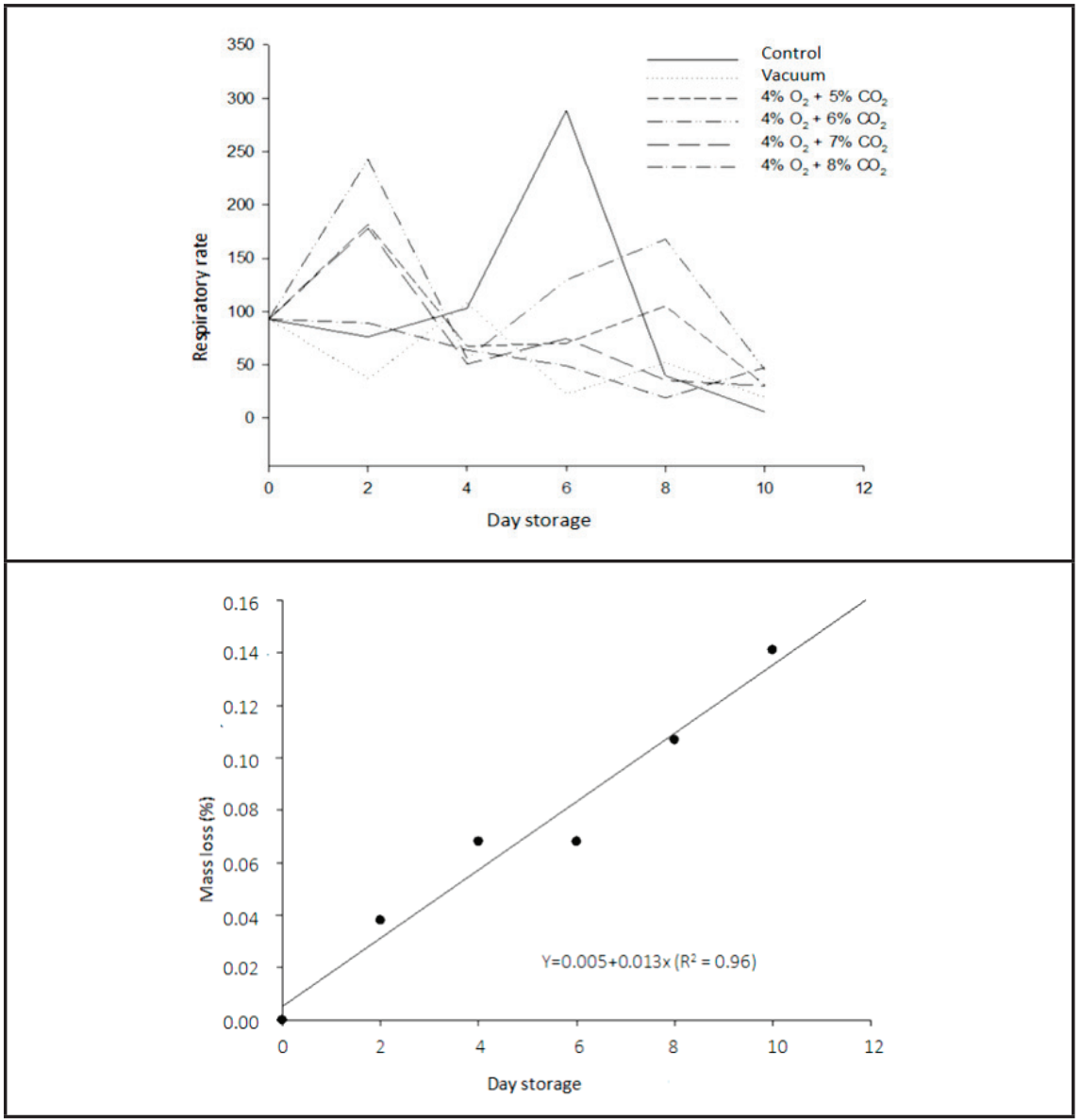

Figure 1. Respiratory rate $\left(\mathrm{mL} \mathrm{CO}_{2} \mathrm{~kg}^{-1} \mathrm{~h}^{-1}\right)$ among the treatments of minimally processed eggplant packed under active modified atmosphere and mass loss (\%) during a 10-day storage. Botucatu, UNESP, 2015. that from processing up to the end of storage period, it ranged from 27.2 to 45.4, making the peel brighter. This increase may be the result of cellular juice accumulated into the vacuum packaging, since this treatment was the one which the most depreciate vegetable quality during storage. According to Arruda et al. (2003), luminosity distinguishes light from dark colors. This attribute ranges from zero for dark colors to 100 for light colors. The lower this value, the greater the degree of depreciation of the product appearance.

For pulp, the authors noticed effect only in storage, with values decreasing for luminosity (Figure 2), ranged from 87.8 to 80.2 , resulting in a loss of $8.7 \%$ at 10 -day storage. This loss in brightness is a consequence of product depreciation, highlighting pulp darkening, corroborating Rinaldi et al. (2009), who working with cabbage and modified atmospheres cited reduction of $8.13 \%$ in luminosity during 16-day storage. On the other hand, Russo et al. (2012), in minimally processed pumpkin in active modified atmosphere, did not observe significant differences for pulp luminosity.

Regression of peel chroma (Table

Table 2. Regression equations for soluble solids (\%), titratable acidity ( $\mathrm{g}$ citric acid $100 \mathrm{~g} \mathrm{pulp}^{-1}$ ), and maturation index between treatments of minimally processed eggplant packed under active modified atmosphere during a 10-day storage. Botucatu, UNESP, 2015.

\begin{tabular}{|c|c|c|c|}
\hline Variable & Treatment & Equation $(x=$ storage $)$ & $\mathbf{R}^{2}$ \\
\hline \multirow{6}{*}{ Soluble solids $(\%)$} & Control & $Y=5.13-0.224 x+0.013 x^{2}$ & 0.49 \\
\hline & Vacuum & $Y=5.13-0.519 x+0.092 x^{2}-0.005 x^{3}$ & 0.84 \\
\hline & $4 \% \mathrm{O}_{2}+5 \% \mathrm{CO}_{2}$ & $Y=5.06-0.249 x+0.015 x^{2}$ & 0.89 \\
\hline & $4 \% \mathrm{O}_{2}+6 \% \mathrm{CO}_{2}$ & $Y=5.04-0.553 x+0.117 x^{2}-0.007 x^{3}$ & 0.75 \\
\hline & $4 \% \mathrm{O}_{2}+7 \% \mathrm{CO}_{2}$ & $Y=5.06-0.638 x+0.121 x^{2}-0.007 x^{3}$ & 0.87 \\
\hline & $4 \% \mathrm{O}_{2}+8 \% \mathrm{CO}_{2}$ & $Y=4.91-0.119 x$ & 0.82 \\
\hline \multirow{6}{*}{ Titratable acidity ( $\mathrm{g}$ of citric acid $100 \mathrm{~g}^{-1}$ ) } & Control & $Y=0.33-0.08 x+0.011 x^{2}-0.0005 x^{3}$ & 0.91 \\
\hline & Vacuum & $Y=0.34-0.08 x+0.012 x^{2}-0.0006 x^{3}$ & 0.66 \\
\hline & $4 \% \mathrm{O}_{2}+5 \% \mathrm{CO}_{2}$ & $\mathrm{Y}=0.34-0.04 \mathrm{x}+0.002 \mathrm{x}^{2}$ & 0.70 \\
\hline & $4 \% \mathrm{O}_{2}+6 \% \mathrm{CO}_{2}$ & $Y=0.33-0.05 x+0.003 x^{2}$ & 0.86 \\
\hline & $4 \% \mathrm{O}_{2}+7 \% \mathrm{CO}_{2}$ & $Y=0.33-0.05 x+0.004 x^{2}$ & 0.83 \\
\hline & $4 \% \mathrm{O}_{2}+8 \% \mathrm{CO}_{2}$ & $Y=0.33-0.05 x+0.003 x^{2}$ & 0.83 \\
\hline \multirow{6}{*}{ Maturation index } & Control & $Y=15.95+3.92 x-0.22 x^{2}$ & 0.88 \\
\hline & Vacuum & $\mathrm{Y}=15.21+3.28 \mathrm{x}-0.27 \mathrm{x}^{2}$ & 0.42 \\
\hline & $4 \% \mathrm{O}_{2}+5 \% \mathrm{CO}$ & $Y=15.63+1.18 x$ & 0.48 \\
\hline & $4 \% \mathrm{O}_{2}+6 \% \mathrm{CO}_{2}$ & $Y=14.26+4.43 x-0.31 x^{2}$ & 0.69 \\
\hline & $4 \% \mathrm{O}_{2}+7 \% \mathrm{CO}_{2}$ & $Y=14.23+4.07 x-0.28 x^{2}$ & 0.62 \\
\hline & $4 \% \mathrm{O}_{2}+8 \% \mathrm{CO}_{2}$ & $Y=14.71+3.66 x-0.31 x^{2}$ & 0.69 \\
\hline
\end{tabular}


Table 3. Regression for peel luminosity, chroma of peel and pulp and peel color (Hue values) among treatments of minimally processed eggplant packed under active modified atmosphere during a 10-day storage. Botucatu, UNESP, 2015.

\begin{tabular}{|c|c|c|c|}
\hline Variable & Treatment & Equation $(x=$ storage $)$ & $\mathbf{R}^{2}$ \\
\hline \multirow{6}{*}{$\begin{array}{l}\text { Peel } \\
\text { luminosity }\end{array}$} & Control & ns & ns \\
\hline & Vacuum & $Y=26.42-0.367 x+0.162 x^{2}$ & 0.89 \\
\hline & $4 \% \mathrm{O}_{2}+5 \% \mathrm{CO}_{2}$ & ns & ns \\
\hline & $4 \% \mathrm{O}_{2}+6 \% \mathrm{CO}_{2}$ & ns & ns \\
\hline & $4 \% \mathrm{O}_{2}+7 \% \mathrm{CO}_{2}$ & ns & ns \\
\hline & $4 \% \mathrm{O}_{2}+8 \% \mathrm{CO}_{2}$ & ns & ns \\
\hline \multirow{6}{*}{$\begin{array}{l}\text { Peel } \\
\text { chroma }\end{array}$} & Control & ns & ns \\
\hline & Vacuum & $Y=5.96+0.154 x+0.181 x^{2}$ & 0.92 \\
\hline & $4 \% \mathrm{O}_{2}+5 \% \mathrm{CO}_{2}$ & ns & ns \\
\hline & $4 \% \mathrm{O}_{2}+6 \% \mathrm{CO}_{2}$ & ns & ns \\
\hline & $4 \% \mathrm{O}_{2}+7 \% \mathrm{CO}_{2}$ & ns & ns \\
\hline & $4 \% \mathrm{O}_{2}+8 \% \mathrm{CO}_{2}$ & ns & ns \\
\hline \multirow{6}{*}{$\begin{array}{l}\text { Pulp } \\
\text { chroma }\end{array}$} & Control & ns & ns \\
\hline & Vacuum & $Y=24.79-0.959 x+0.590 x^{2}-0.05 x^{3}$ & 0.94 \\
\hline & $4 \% \mathrm{O}_{2}+5 \% \mathrm{CO}_{2}$ & ns & ns \\
\hline & $4 \% \mathrm{O}_{2}+6 \% \mathrm{CO}_{2}$ & ns & ns \\
\hline & $4 \% \mathrm{O}_{2}+7 \% \mathrm{CO}_{2}$ & ns & ns \\
\hline & $4 \% \mathrm{O}_{2}+8 \% \mathrm{CO}_{2}$ & ns & $\mathrm{ns}$ \\
\hline \multirow{6}{*}{ Peel color } & Control & ns & ns \\
\hline & Vacuum & $\mathrm{Y}=2.72-1.151 \mathrm{x}+2.841 \mathrm{x}^{2}-0.200 \mathrm{x}^{3}$ & 0.86 \\
\hline & $4 \% \mathrm{O}_{2}+5 \% \mathrm{CO}_{2}$ & $Y=4.30+3.597 x-0.347 x^{2}$ & 0.78 \\
\hline & $4 \% \mathrm{O}_{2}+6 \% \mathrm{CO}_{2}$ & ns & ns \\
\hline & $4 \% \mathrm{O}_{2}+7 \% \mathrm{CO}_{2}$ & $Y=0.587+7.939 x-0.745 x^{2}$ & 0.42 \\
\hline & $4 \% \mathrm{O}_{2}+8 \% \mathrm{CO}_{2}$ & $Y=0.683+6.599 x-0.579 x^{2}$ & 0.41 \\
\hline
\end{tabular}

3) was significant only in vacuum treatment. The eggplants stored in this system showed higher color saturation, with values ranging from 6.4 to 25.3. Hue angle (peel) in vacuum treatment ranged from 2.76 to 78.3 , changing from red-violet to orange. However, using joint analysis for chroma and luminosity values and according to Minolta (1998), a color change from a very dark violet red to dirty orange was noticed. The other treatments kept the color during shelf life. In relation to pulp chroma (Table 3 ), the vacuum treatment lost color saturation, making the color lighter. Pale yellow color (hue pulp) of the eggplant slices was kept during the shelf life (103.2 to 93.3), regardless the treatment (Figure 2). Contrary, in a study with minimally processed pumpkin, the vacuum treatment kept the best color for the product (Silva et al., 2009). Given the above, the authors concluded that the vacuum treatment showed a darker pulp color and that the peel of those slices lost the purple color typical of this cultivar, making it reddish. This statement was confirmed by the results of visual analysis and purchase intention (Table 4), the slices stored in vacuum packaging obtained the worst grades for visual analysis (1.5) and the lowest purchase intention (1.1), being classified as terrible and certainly would not buy.

Color is the most attractive quality attribute when buying eggplant.

Table 4. Regression for visual analysis (grades) and purchase intention (grades), among treatments of minimally processed eggplant packed under active modified atmosphere during a 10-day storage. Botucatu, UNESP, 2015.

\begin{tabular}{|c|c|c|c|}
\hline Variable & Treatment & Equation $(x=$ storage $)$ & $\mathbf{R}^{2}$ \\
\hline \multirow{6}{*}{ Visual analysis (grades) } & Control & $\mathrm{Y}=5.00-1.129 \mathrm{x}+0.217 \mathrm{x}^{2}-0.013 \mathrm{x}^{3}$ & 0.99 \\
\hline & Vacuum & $Y=4.99-1.37 x+0.182 x^{2}-0.007 x^{3}$ & 0.99 \\
\hline & $4 \% \mathrm{O}_{2}+5 \% \mathrm{CO}_{2}$ & $Y=4.99-0.996 x+0.142 x^{2}-0.007 x^{3}$ & 0.95 \\
\hline & $4 \% \mathrm{O}_{2}+6 \% \mathrm{CO}_{2}$ & $Y=5.00-0.821 x+0.141 x^{2}-0.007 x^{3}$ & 0.99 \\
\hline & $4 \% \mathrm{O}_{2}+7 \% \mathrm{CO}_{2}$ & $\mathrm{Y}=5.00-0.800 \mathrm{x}+0.151 \mathrm{x}^{2}-0.009 \mathrm{x}^{3}$ & 0.99 \\
\hline & $4 \% \mathrm{O}_{2}+8 \% \mathrm{CO}_{2}$ & $Y=4.89-0.323 x+0.016 x^{2}$ & 0.95 \\
\hline \multirow{6}{*}{ Purchase intention (grades) } & Testemunha & $\mathrm{Y}=5.00+1.196 \mathrm{x}-0.232 \mathrm{x}^{2}+0.014 \mathrm{x}^{3}$ & 0.99 \\
\hline & Vácuo & $Y=5.00+1.374 x-0.185 x^{2}-0.009 x^{3}$ & 0.99 \\
\hline & $4 \% \mathrm{O}_{2}+5 \% \mathrm{CO}_{2}$ & $\mathrm{Y}=4.94-0.666 \mathrm{x}+0.041 \mathrm{x}^{2}$ & 0.96 \\
\hline & $4 \% \mathrm{O}_{2}+6 \% \mathrm{CO}_{2}$ & $\mathrm{Y}=4.95-0.504 \mathrm{x}+0.038 \mathrm{x}^{2}$ & 0.85 \\
\hline & $4 \% \mathrm{O}_{2}+7 \% \mathrm{CO}_{2}$ & $\mathrm{Y}=4.94-0.370 \mathrm{x}+0.018 \mathrm{x}^{2}$ & 0.94 \\
\hline & $4 \% \mathrm{O}_{2}+8 \% \mathrm{CO}_{2}$ & $Y=5.00-0.811 x+0.145 x^{2}-0.009 x^{3}$ & 0.99 \\
\hline
\end{tabular}




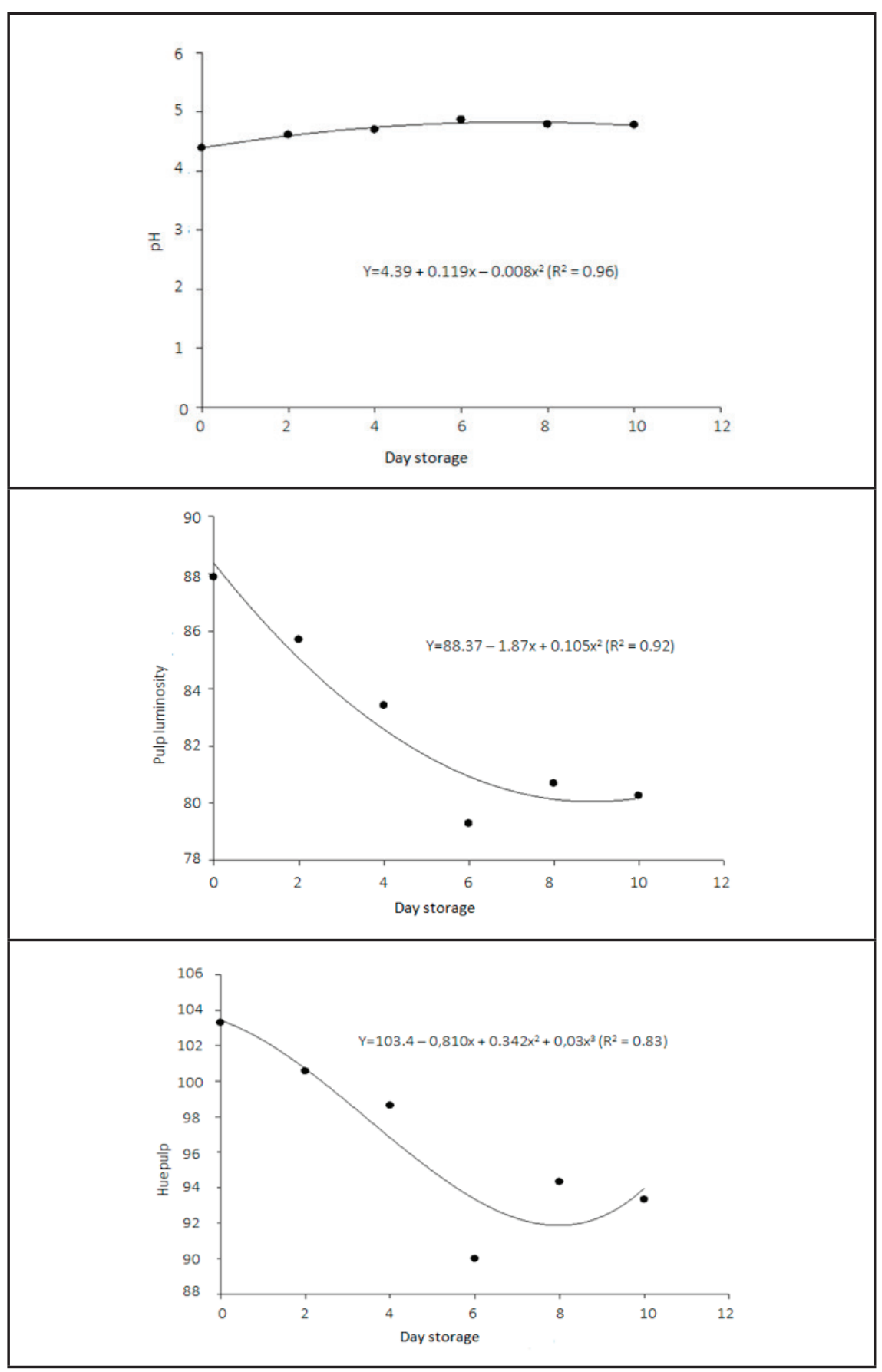

Figure 2. Values of $\mathrm{pH}$, luminosity, hue of pulp for treatments of minimally processed eggplant packed under active modified atmosphere during a 10-day storage. Botucatu, UNESP, 2015.

Colorful and shining products are the most preferred, being an important characteristic in processed products (Chitarra \& Chitarra, 2005; Miguel et al., 2010). In visual analysis (Table 4 ), the eggplant packed in $6 \% \mathrm{CO}_{2}$ packaging obtained the best grades, reaching grade 3.9 (good) on day 10 . The worst storage was observed in vacuum packaging, since it was classified as bad (1.9) on day 4 , reaching a terrible grade, 1.5. For the other modified atmospheres, grades ranged from 2.5 to 3.1 (bad to regular). Miguel et al. (2010) stated that product preference test should be applied in order to know the taste and meet the demands of the consumer. Purchase intention showed the same behavior. The lowest purchase intention was related to the vacuumpacked product, from day 4 on, grade 1.9 (probably would not buy). Eggplants in active modified atmosphere, $6 \% \mathrm{CO}_{2}$, at the end of shelf life, obtained grade 3.5 (classified between probably would buy to maybe would buy). Dantas et al. (2005) mentioned the importance of market surveys before developing products or even improving existing products, aiming to identify market segments making it possible to improve marketing strategies.

Minimally processed eggplant, stored at $5^{\circ} \mathrm{C}$ temperature and $90 \%$ UR, kept in modified atmosphere $\left(4 \% \mathrm{O}_{2}\right.$ $+6 \% \mathrm{CO}_{2}$ ), obtained better grades in visual analysis and purchase intention during a 10-day storage period.

Vacuum packaging is not recommended to keep minimally processed eggplant. The eggplants were probably under anaerobic conditions.

\section{REFERENCES}

ARAÚJO, FMMC; MACHADO, AV; CHITARRA, AB. 2005. Efeito da atmosfera modificada ativa na qualidade do melão 'Orange Flesh' minimamente processado. Ciência e Agrotecnologia 29: 817-823.

ARRUDA, MC; JACOMINO, AP; KLUGE, RA; AZZOLINI, M. 2003. Temperatura de armazenamento e tipo de corte para melão minimamente processado. Revista Brasileira de Fruticultura 25: 74-76.

ARRUDA, MC; JACOMINO, AP; TREVISAN, MJ; JERONIMO, EM; MORETTI, CL. 2011. Atmosfera modificada em laranja 'Pêra' minimamente processada. Bragantia 70 : 664-671.

BLEINROTH, EW; ZUCHINI, AG; POMPEO, RM. 1976. Determinação das características e mecânicas de variedades de abacate e sua conservação pelo frio. Coletânea ITAL 7: 29-81.

BRASIL - MINISTÉRIO DA SÁUDE. Instituto Adolfo Lutz. Métodos físicos e químicos para análise de alimentos. 4. ed. São Paulo: Instituto Adolfo Lutz, 2008. 1020p.

CATALANO, AE; SCHILIRÓ, A; TODARO, A; PALMIERI, R; SPAGNA, G. 2007. Enzymatic degradations on fresh-cut eggplants differently packaged. Acta Horticulturae 746: 469-474.

CHITARRA, MIF; CHITARRA, AB. 2005. Póscolheita de frutos e hortaliças: fisiologia e manuseio. 2. ed. Lavras: UFLA. 785p.

DANTAS, MIS; DELIZA, R; MINIM, VPR; HEDDERLEY, D. 2005. Avaliação da intenção de compra de couve minimamente processada. Ciência e Tecnologia de Alimentos 25: $762-$ 767.

FONSECA, SC; OLIVEIRA, FAR; BRECHT, JK. 2002. Modelling respiration rate of fresh fruits and vegetables for modified atmosphere packages: a review. Journal of 
Food Engineering 52: 99-119.

GHIDELLI, C; MATEOS, M; ROJAS-ARGUDO, C; PÉREZ-GAGO, MB. 2014. Extending the shelf life of fresh-cut eggplant with a soy protein-cysteine based edible coating and modified atmosphere packaging. Postharvest Biology and Technology 95: 81-87.

HOFFMANN, FL. 2001. Fatores limitantes à proliferação de microorganismos em alimentos. Brasil Alimentos 9: 23-30.

JACXSENS, L; DEVLIEGHERE, F; RAGAERT, P; VANNESTE, E; DEBEVERE, J. 2003. Relation between microbiological quality, metabolite production and sensory quality of equilibrium modified atmosphere packaged fresh-cut produce. International Journal of Food Microbiology 83: 263-280.

KLUGE, RA; COSTA, CA; VITTI, MCD; ONGARELLI, MG; JACOMINO, AP; MORETTI, CL. 2006. Armazenamento refrigerado de beterraba minimamente processada em diferentes tipos de corte. Ciência Rural 36: 263-270.

KLUGE, RA; GEERDINK, GM; TEZOTTOULIANA, JV; GUASSI, SAD; ZORZETO, TQ; SASAKI, FFC; MELLO, SC. 2014. Qualidade de pimentões amarelos minimamente processados tratados com antioxidantes. Semina: Ciências Agrárias 35: 801-812.

LI, X.; JIANG, Y.; LI, W.; TANG, Y.; YUN, J.
2014. Effects of ascorbic acid and high oxygen modified atmosphere packaging during storage of fresh-cut eggplants. Revista de Agroquimica y Tecnologia de Alimentos 20: 99-108.

MEILGAARD, M.; CIVILLE, GV; CARR, BT. 1999. Sensory evaluation techniques. 3. ed. New York: CRC. 281 p.

MIGUEL, ACA; ABRAHÃO, C; DIAS, JRPS; SPOTO, MHF. 2010. Modificações sensoriais em abacaxi 'Pérola' armazenado à temperatura ambiente. Ciência e Tecnologia de Alimentos 29: 504-507.

MINOLTA, K. 1998. Comunicação precisa da cor: controle de qualidade da percepção à instrumentação. Osaka: Konika Minolta Sensing Inc. 59p.

MORETTI, CL; PINELI, LO. 2005. Qualidade química e física de berinjelas submetidas a diferentes tratamentos pós-colheita. Ciência e Tecnologia de Alimentos 25: 339-344.

RINALDI, MM; BENEDETTI, BC; SARANTÓPOULOS, CIGL; MORETTI, CL. 2009. Estabilidade de repolho minimamente processado sob diferentes sistemas de embalagem. Ciência e Tecnologia de Alimentos 29: 310-315.

ROJAS-GRAU, MA; RAYBAUDI-MASSILIA, RM; SOLIVA-FORTUNY, R; MARTINBELLOSO, O. 2009. The use of packaging techniques to maintain freshness in fresh-cut fruits and vegetables: a review. International
Journal Science Technology 44: 875-889.

RUSSO, VC; DAIUTO, ER; SANTOS, BL; LOZANO, MG; VIEITES, RL; VIEIRA, MRS. 2012. Qualidade de abóbora minimamente processada armazenada em atmosfera modificada ativa. Semina: Ciências Agrárias 33: 1071-1084.

SHUKLA, V; NAIK, LB. 1993. Agro-techniques of Solanaceous vegetables. Malhotra Publishing House 5: 364-399.

SILVA, AVC; OLIVEIRA, DSN; YAGUIU, P; CARNELOSSI, MAG; MUNIZ, EN; NARAIN, N. 2009. Temperatura e embalagem para abóbora minimamente processada. Ciência e Tecnologia de Alimentos 29: 391394.

STEFFENS, CA; AMARANTE, CVT; ALVES, EO; TANAKA, H; BRACKMANN, A; BOTH, V. 2009. Armazenamento de ameixas 'Laetitia' em atmosfera modificada.Ciência Rural 39: 2439-2444.

TOIVONEN, PMA; DEDELL, JR. 2002. Physiology of fresh-cut fruits and vegetables. In: LAMIKANRA, O. (ed). Fresh-cut fruits and vegetables. Science, Technology and Market. Florida: CRC Press, Boca Raton. p.91-123.

VIEITES, RL; RUSSO, VC; DAIUTO, ER. 2014. Qualidade do abacate 'Hass' frigoarmazenado submetido a atmosferas modificadas ativas. Revista Brasileira de Fruticultura 36: 329338. 